\title{
Trouble Wherever They Went: American Missionaries in Anatolia and Ottoman Syria in the Nineteenth Century
}

\author{
Jeremy Salt \\ Bilkent University \\ Ankara, Turkey
}

W hen the first missionaries sent by the ABCFM (American Board of Commissioners for Foreign Missions) set off from New England early in the nineteenth century, the Ottoman Empire was about to enter a period of protracted reorganization and reform. The intention was to modernize and thereby strengthen the empire. Of all the principles and abstract ideas on which reforms were based, the equality of all the sultan's subjects before the law regardless of their religious background was perhaps the most difficult to approach and then put into practice. The first Tanzimat reform decree of 1839 "kindled the rage of the old Mussulmans" and by 1870 the Grand Vizier himself was admitting that Ottoman bureaucrats "could not understand the full adoption of a new system which was repugnant to all their old prejudices."

Thus, at the time American missionaries were beginning to spread out across the empire, the question of religion had become one of the most sensitive elements in the reform program, with the "old Mussulmans" defending their rights as they understood them and the Christians occasionally bold enough to put the new edicts to the test in public, sometimes with unfortunate results: the flaunting of their recently proclaimed rights after 1856 led to public disturbances in Palestine. ${ }^{3}$ Precisely what the two principal reform edicts (1839 and 1856) had granted in the way of religious freedom was open to dispute between all the interested parties: the Ottoman government, the Eastern churches, the Protestant missionaries and European governments 
among them, but the missionaries took the view that they had opened the way to the full range of their activities.

Insofar as Ottoman reform was concerned, European interests after the Congress of Berlin (1878) centered on reforms that would enhance the status of Christians and particularly the Armenians. The interests of the European governments might have been in some way humanitarian, but the religious question was also a political one directly related to European (and especially Anglo-Russian-French) rivalry over the Ottoman Empire and thus the European balance of power. After Berlin, the British pushed ahead with their own reform program, which in contradistinction to the centralizing policies of the Ottoman government, sought a special administrative regime for the six Eastern Anatolian provinces along with the separation of the main ethnoreligious groups (Kurds, Turks and Armenians) and the granting of what would be regarded by the Muslims and the Ottoman government as special privileges for the Armenians. By the 1880s, the Armenian revolutionary committees within the Ottoman Empire were taking their cue from European sympathy and the autonomy the Bulgarians had been granted at Berlin and had embarked on a program of propaganda and anti-government violence.

It was in this charged atmosphere that the American missionaries began seeking converts to the Protestant faith. Their activities generated not only the opposition of the Eastern churches but the suspicion of the Ottoman government. Yet they radiated confidence even in the most difficult and dangerous circumstances. Their mission was to carry Gospel truth to the 'nominal' Christians of the Eastern churches and they would do it come what may: they also hoped to influence Muslims through their teaching and good example and perhaps one day approach them directly (which some of the missionaries did anyway). Their principal enemies were the priests and higher ecclesiastics of the Eastern churches who tried to check their advances by repeatedly anathematizing any of their flock who had dealings with the Protestants. In the abstract, the great enemy was 'untruth'; not just the 'untruth' of the churches of the Eastern rites but of the whole edifice of Islam. Whatever they might declare about their good intentions, they freely expressed their hostility to the Eastern churches and to Islam in their private correspondence and in missionary journals published in the United States.

\section{The Missionary 'Planting'}

Nothing is more expressive of missionary fervor than the names chosen for them by their parents. Asahel, Azariah, Ezra, Benjamin, Jonas, Selah, Nathaniel, Abner, Alpheus, Nehemiah, Titus, Cyrus, Elijah, Hiram, Moses, Elisha, Daniel, Isaac, Adoniram, Jedediah, Calvin, Jeremiah and Joseph all spoke of the puritanism of the churches, colleges and seminaries of Andover, Salem, 
Bradford, Newburyport and Boston once the revolution had "cleared away the fogs of infidelity" "and revived Christianity. The establishment of the ABCFM (American Board of Commissioners for Foreign Missions) was undertaken, followed by the expression of student concern at the "moral darkness" of Asia. In the period of the 'planting' (1810-1850), the first two missionaries and their wives (Adinoram Judson Junior and Ann Haseltine Judson and Samuel and Harriet Newell) were dispatched to India and Ceylon, arriving in Calcutta on June 17, 1812. "The missionaries did not have to wait long for their trials," writes the historian of the ABCFM. "Strangely the first opposition was not from the people of the land but from men of their own race. The East India Company, whose tenure of special privilege was then being sharply protested in England, was doing its utmost to keep missionaries out of the country where their observant eye was dreaded." Two days after landing in Calcutta, the governor-general directed the missionaries to leave the country. The story thereafter becomes a fiasco. Newell took passage on a ship for Ceylon; Judson fled to Burma (and became a Baptist once back in Calcutta); other missionaries who had arrived from Mauritius were arrested (following the declaration of war between the United States and Britain) and it was not until 1814 that the East India Company, following representations by William Wilberforce, relented and allowed the missionaries to stay. ${ }^{6}$

In India, the missionaries declared war on practices that they found objectionable: in their schools and churches, they attempted to 'stamp out' the caste system and boldly sought converts even among the Brahmans. "... the persecution of Brahman converts was bitter, parents wailing over a Christian son who had become a Christian as if he were dead" - a reaction that was to foreshadow the treatment of converts from the Eastern churches in the Ottoman Empire, which was, of course, the focal point of their attention all along: "From the beginning the American Board had its eye on the Holy Land. It seemed intolerable to its founders that Christianity's birthplaces should be forever in the grip of Islam or left to exhibit a form of Christianity, ancient and entrenched but for the most part lifeless" ${ }^{8}$ — but whether Christian or Muslim, all of it was part of the "stagnant barbarism" that pervaded the Ottoman Empire "under the oppressive hand of the sultan-caliph in Constantinople." The characteristics of the dominant religion of the Ottoman Empire were tied in with the perceived characteristics of the Turkish people: as one missionary wrote in 1888, "the Turk is no doubt as fanatical at heart as he always was. The fear of other nations only prevents him from putting his fanaticism into practice. There is above all else a Mohammedan. All others are infidels destined to eternal torment hereafter and worthy only of torment here." ${ }^{10}$ This view of entrenched Muslim hostility towards Christians was standard fare in the continuing Christian polemic against Islam. The missionaries could speak 
kindly of individual Muslims while remaining vehemently hostile to Islam as a system of belief: in their letters they spoke of systematically penetrating and "occupying" Ottoman lands as if they were enemy territories and indeed it would be fair to say that they did come to the Ottoman Empire to conquer - to win the nominal Christians over to Gospel truth and convert Muslims when circumstances were more favorable. It was no wonder that the response of the Eastern churches was so ferocious and that the missionaries met with such suspicion of their motives amongst Muslims and the Ottoman government alike.

The first two representatives of the ABCFM (Pliny Fisk and Levi Parsons), arrived in the 1820 s and were soon followed by others. Working closely with English missionaries and enjoying the protection of the English government, they began spreading out across the Ottoman Empire in search of suitable locations for their schools, churches and colleges. They were indefatigable gatherers of information and associated power with education and knowledge. "In no man is knowledge more really power than the schoolmaster" the Prudential Committee of the ABCFM noted in its instructions to a departing missionary, "and by none is it more valued, by none more certainly used." 11 Their attention was concentrated on the "nominal" Christians of all the Eastern rites, but in Istanbul, William Schauffler's special task was to reach Sephardi Jews "who upon their expulsion from Spain had crowded into Constantinople more of their race than were in any other city of the world." 12

Discretion was regarded as essential. No approach at all was to be made to the Muslims. Neither was any direct attempt to be made to proselytize among the Armenians. The missionaries attended services in both Greek Orthodox and Gregorian Armenian churches but confined their attempts to reach Eastern Christians to "such personal interviews as they might have with those who called upon them or whom they might meet as they went here and there." ${ }^{13}$ According to missionary Goodell: "We tell them frankly you have enough sects among you already and we have no design of setting up a new one or of pulling down your churches or drawing any members from them in order to build up our own." ${ }^{14}$ Others repeated the same message. Fearing that under pressure from the patriarchs the missionaries might be expelled, missionary Schauffler wrote,

Supposing therefore that we should have to go, we drew up a protestation of our innocence declaring among other things that we had not come to draw away any members from Christian churches or build up a Protestant denomination but simply to offer our help to the Eastern churches in returning from the abuses gradually obtaining ground and the superstitious practices which they themselves acknowledge to be unscriptural, according to their own scriptures ... Our plea of non- 
sectarianism was then strictly true. At the time, there existed no intention or expectation of creating a Protestant denomination. How far the representatives of foreign powers (apart from our own) believed our report on the subject I do not know. It seems probable to me that they thought it a mere pretence, for sectarianism is the life of all these religious bodies, including the Turks. ${ }^{15}$

Such protestations were certainly likely to count for little among the representatives of France and Russia - under the capitulations, the self-styled protectors respectively of Ottoman Orthodox and Latin Christians - whose diplomatic influence "was used to the utmost in high places against the missionaries." ${ }^{16}$

The missionaries might not have been thinking of official recognition of a Protestant millet at that stage but there could be no doubt about their other objectives. They wanted (by their own admission) to lead Christians away from the erroneous doctrines of the Eastern churches and eventually arrive at the point where the Muslim majority could be approached. They were determined and underneath the pious declarations of good intentions there was an unmistakably aggressive tone. When Cyrus Hamlin set out for Istanbul (where he was to establish Robert College and in so doing show "those qualities which made him the terror of the evasive Turk ${ }^{n 17}$ ), he was instructed by the Prudential Committee of the ABCFM:

You are not sent among these churches to proselytize. Let the Armenian remain an Armenian if he will and the Greek a Greek and the Nestorian a Nestorian and the oriental an oriental . . Modes of government both civil and ecclesiastical are doubtless important but they are not the great thing . . . It may also be said of the rites and ceremonies of these sects that they are mere outworks which it is not necessary for you to remove before you come to the citadel; and an assault on them will awaken more alarm, more fierce hostility, more general and decided opposition than upon the citadel itself . . . Direct your whole force to the principal post and when that is taken the others will fall at once... Your great business is with the fundamental doctrines and duties of the gospel and these you should derive invariably and directly from the Holy Scriptures. ${ }^{18}$

Such language was a fair indication of the ultimate intentions of the missionaries and as we shall soon see, the Eastern churches were not deceived by their stealthy tactics.

\section{"Nominal" Christians and the "Bible Men"}

However discreet the missionaries claimed to be in the field, there was no dissembling in their correspondence. In a communication on "The Cause of Opposition to Protestant Doctrines in Syria," missionary Goodell writes in 1829 
that "a nominal Christianity, where the doctrines are obscured by human inventions and the precepts modified so as to consist in sin, is destitute of the controlling power inherent in the Christianity of the New Testament. It is nullified as to all the purpose of revelation; it has no more tendency to ameliorate the human character than paganism; and perhaps even a retributive hardness of heart and spiritual folly may be induced upon the ecclesiastics by their profane manner of treating worldly things." ${ }^{19} \mathrm{Mr}$. Goodell referred to the thousand provocations coming from the nominal Christians of Syria, which had almost broken the missionaries' hearts; however "had they cherished heavenly tempers we should not have been sent to them. It was because they were selfish and proud and covetous and thieves and extortioners and 'inventors of evil things,' possessing unholy characters and hateful tempers that we came here. 'They that be whole have no need of a physician but they that be sick. ${ }^{m 20}$ Full responsibility for this state of affairs was laid on the shoulders of the ecclesiastics of the Eastern churches whom the missionaries regarded from the patriarch down to the village priest as being narrow-minded, fanatical and self-serving. Their "blushing immorality"21 extended to the most iniquitous sins: "The ignorance and sin that prevail to a great extent among the clergy and especially in the convents seem almost to surpass those of Sodom" wrote missionary Goodell in a communication on "The Cause of Opposition to Protestant Doctrines in Syria." 22 When such a corrupted form of Christianity was combined with the influence of "Turkish tyranny and bribery," integrity and good faith were destroyed and in their place were introduced "lying, deception and every kind of hypocrisy." 23

This all added up to quite an indictment and the ecclesiastics of the Eastern churches struck back from the beginning. Perhaps they knew something of what the missionaries were saying in their dispatches sent back to the Missionary Herald, but in any case, they were not deceived by the pious declarations of good intentions that came from the "Bible men." They were as outraged by missionary pretensions as the missionaries were by theirs. They were not going to allow the Protestants to lead their flocks away under their noses and the first twenty years in particular of the ABCFM presence in the Ottoman Empire is punctuated by the exhortations of the patriarchs against the "Bible men." The missionaries were denounced in such thunderous terms that one can almost see the fire and brimstone descending on their heads. They were described as servants of the devil "covered with sheep's clothing but [who] within are ravening wolves" - or sometimes "prowling wolves." ${ }^{24}$ The Rev. W. M. Thomson writes in the journal he kept while traveling in 1836 of how under the influence of the Maronite clergy, the town crier at Brumanna on Mt. Lebanon was sent out "proclaiming in the name of the emeer that no one should speak to us, visit us or befriend us in any manner whatever. Those 
who spoke to us should have their tongues cut out; those who sold to us should be bastinadoed and have their houses burnt down, their orchards felled, etc." 25

The Greek church was no less vehement in its denunciations of the missionaries. There was continuing trouble at Hasbeyya where missionary Whiting writes in 1848 of the patriarch's bull of excommunication being published "not only in Hasbeiya but also in all that part of the country. The purport of it was to denounce the Protestants as accursed of God and man and to require all persons belonging to the Greek Church to separate from them entirely, forbidding them to deal, speak or hold any intercourse with them on pain of bringing the same fearful curse upon themselves. The sentence was carried into effect to the letter. And not only did the Greeks adopt this system of non-intercourse; but being the most numerous and influential sect in Hasbeiya they induced the other sects to join them in it." ${ }^{26}$

The same attempts to drive the missionaries were being made by the Gregorian Armenian church, with the patriarch banning the reading of missionary material and forbidding any Armenian from associating with the missionaries on pain of excommunication: ${ }^{27}$ the missionaries were denounced as "satanic heresiarchs from the caverns of hell and the abyss of the northern ocean." ${ }^{28}$ Lest it be thought that hostility to the Protestants was confined to other Christians, their gospel work was repulsed just as vehemently by the Chief Rabbi who in 1836 "strictly charged all Jews on pain of imprisonment not to visit Pera without a passport,"29 according to the missionary William G. Schauffler, who had come to the Ottoman Empire specifically to work among the Jews; Pera, of course, was where missionary activities were based.

\section{The Ostracism of "Nominal" Christian Converts}

An area often overlooked in studies of the missionary presence is the effect on those "nominal" Christians who were won over by Protestant teaching and consequently were subject to ostracism within their own communities. Given the centrality of the church in the lives of all these millets, the "nominal" Christian who decided to follow the teachings of the Protestant missionaries rather than the doctrines of his or her own church risked total ostracism by his community. This was not simply a matter of being shut out of the church but of losing employment and of being cursed in the streets and of being spurned by people who were once neighbors and friends. William G. Schauffler writes that the Armenian patriarchs "tried sundry means to crush the spark of religious inquiry and the desire for instruction. ${ }^{30}$ We are told that a "new era" of persecution of Armenians began in 1844 when the newly appointed Patriarch Matteos "used all his ingenuity" to destroy the evangelicals he had once favored (or so the missionary account claims). "Armenians in business 
found their shops boycotted; teachers and priests were banished; men and women were stoned in the streets, hung up by the thumbs, spit upon and smitten in the face, tortured with the bastinado, thrown into prison without open charge or trial. Spies were everywhere." ${ }^{31}$ Their houses were closely watched and indeed "the very servants of the families would have betrayed them. ${ }^{n 2}$ Missionaries did what they could to support Armenians who had turned away from their own church and suffered in consequence. "The straits of the missionaries were great in view of the many families thrown into the streets and heads of families turned out of their shops and stores where they used to gain a livelihood." Money was raised locally from English residents and brought from abroad until "persecution" of the beleaguered Armenians ceased. ${ }^{33}$ The sufferings of the Armenians certainly fit in with the missionary view of what they and others should be prepared to face for the sake of their Christian beliefs.

This was of course a decade when the question of religious freedom had been opened up by the Hatti Serif of 1839. It was not just the freedom foreign Christians thought Muslims should have to convert, an issue brought to a head by the executions in 1844 of two Muslim apostates, but the general question of religious freedom which struck generally at the hold of the Eastern churches over their communities and provides the context in which the vehemence of their response to Protestant missionary work can be understood.

The period of "persecution" of Armenian defectors in the 1840s was not an isolated occasion either in time or place. We are told of continuing attacks on converts and of a Protestant burial in Istanbul being prevented by a "yelling mob. ${ }^{34}$ In the Eastern provinces, a "native" preacher sent from Sivas to the missionary outstation at Derende was abused and beaten by the principal Armenian of the village, who then "proceeded to the preacher's room where he dashed in the locked door and began pulling down and abusing the Bibles and other books and called for fire to burn them up. ${ }^{35}$ At Yenije, also near Sivas, Protestant Armenians were refused a place for their dead in the cemetery. The preacher was threatened and accused of blasphemy and finally a group of Armenians "broke in upon the little band of Protestants during their Sabbath afternoon service a few weeks ago and, after trying in vain to intimidate them, seized the preacher and violently dragged him out of the room, beating him and heaping all manner of abuse on him and trampling his Testament under their feet in the street. After carrying him a few rods out of the village they turned him adrift, threatening to kill him if he attempted to return. With bare head and without shoes he picked his way through the mud to a neighboring village." Perhaps we should not be surprised to read that the preacher later "left our employ." 36 Harassment extended to the colporteurs, whose job it was to distribute Bibles and missionary tracts 
around the countryside, while at Gurun the Protestants had to rebuild a new chapel when "by the malice of some unknown enemy" the old one was burnt down. ${ }^{37}$

Suspicion of the missionaries and resentment of their proteges cannot be separated from the general social and political context of the times. After the Congress of Berlin in 1878, the "Armenian question" was inscribed on the European diplomatic agenda along with the general question of Ottoman reform. What reform meant depended on who was talking about it: in the official Ottoman mind, reform meant such changes applied across the board that would strengthen the empire in the face of internal decline and external threat, but to the European powers and especially to Britain, reform was taken by many as meaning such changes as would benefit Ottoman Christians and especially the Armenians. They were regarded as a suffering Christian minority and the whole emphasis of the British program for reform in the Ottoman Empire after 1878 was directed to redressing their grievances and uplifting their status. The other agenda besides the stated one of humanitarian concern was national self interest and especially the need to prevent Russia from using the Armenians in one way or another, but all the Muslims saw from the isolated perspective of the Eastern Anatolian provinces was Christian favoritism at their expense with consequences that shall be briefly surveyed later.

In the mountains of Lebanon, missionary activities caused similar problems for Maronites and Greek Orthodox Christians who turned away from their established churches. In 1823, an order from the Maronite Patriarch was read out in all churches requiring "all of that large communion under his jurisdiction who had received any of the books sent out by the Bible Society to return or publicly burn them," ${ }^{38}$ these books being regarded as "neither Mussulman, Jewish nor Christian," and to have no association with the missionaries "in spiritual things or whatever concerns the Christian religion" or to study in their schools. ${ }^{39}$ The ban extended to all social and commercial intercourse with the missionaries. There was to be "neither buying nor selling, neither borrowing nor lending, neither giving nor receiving" or even sharing a house with them: "Let no-one dwell out with them as a hired man or servant in any capacity whatever. ${ }^{n+0}$ The punishment for those who defied the church was not slow in coming: a woman employed by the missionaries who was turned away at the door of the church and a man "whose whole family rose against him and particularly his mother"; a woman beaten when she went to bake Sabbath bread at the common oven; and in the Lebanese mountain village of Ihdin, the excommunication of an entire family for associating with the Protestants and accepting their teachings: "They are therefore accursed, cut off from all Christian communion and let the curse envelop them as a rope and spread through all their members like oil and break them in pieces like a potter's 
vessel and wither them like the fig tree cursed by the mouth of the Lord himself; and let the evil angel rule over them to torment them day and night, asleep and awake and in whatever circumstances they may be found ... Let them be avoided as a putrid member and as hellish dragons. ${ }^{n 1}$ The effects of the bursting of such vials of wrath on the heads of disobedient Christians can be imagined. They lived in close-knit communities. Families were bound together and to the church and like the Armenians, the issuing of such a declaration would be followed by complete social and commercial ostracism unless and until they repented (as the family which was the particular object of the anathema quoted apparently did). ${ }^{42}$

This was a fearful price to pay for religious belief and Greek Orthodox Christians attracted to the missionaries were subject to the same bans and similar "frightful penalties" from their patriarchs. ${ }^{43}$ In 1848 , missionary Whiting refers to the effects on local people of the bull of excommunication published in the Greek churches in Hasbeyya and surrounding district:

The consequence was that no Protestant could buy or sell or transact any business except with his fellow Protestants, and most of them being poor and dependent upon their daily labor for support, they were at once thrown out of all productive employment and cut off from the means of living. Of course this reduced them immediately to a state of great distress. It seems as though they must have starved but for the kindness of one or two of their number who are men of property and had some funds and stores from which they generously supplied the needs of those who were in distress. But these individuals, though better off than the rest, were of course not able to support the whole company of Protestants consisting of some fifty or sixty souls; and besides their own business and resources were stopped. They were compelled to pay every piastre that they owed but could collect nothing of what was due to them. Whoever chose might refuse to pay them their just debts or even deny their claims together. There was no redress; for the Governor, whose duty it is to compel people to pay their debts, would render them no assistance. In fact it was plain enough that the Governor was determined to support the Patriarch and his party in their iniquitous combination to ruin the Protestants. And for his persecuting zeal in their cause, nobody doubts that he is well paid. ${ }^{44}$

Missionary Benton tells a similar story from Aleppo. Christians responding to the Protestant message

. . have their books wrested from them. They are even deprived of their usual employment, ridiculed, threatened and made the sport of children in the streets yet they are annoyed in such ways that they can scarcely think of seeking redress. Although the Pasha has written orders from Constantinople to give them protection, teachers have been deprived of 
their schools; parents and children have been set at variance; wives have left the dwellings of their husbands, declaring that they could not live any longer with them. When a man shows his inclination to search the scriptures and gets possession of a Bible the priests throng his house from morning till night to task and vex and wear out his patience. If they can they will get the Bible into their hands. If at length he does not yieid they put his house under an interdict and not one of their number approaches it. Some are stoned by the children in the streets. Others are turned out of doors by their friends. Anathemas, excommunications, bribes and misrepresentations are held up before the minds of the people to dissuade them from intercourse with us and with the Book of Life. ${ }^{+5}$

There are countless stories coming out of this period of Ottoman Syria of families divided amongst themselves, of threats, beatings, stonings, insults in the marketplace, of people too afraid to appear in the street, of what the missionaries would regard as martyrdom (the death of the first Protestant "martyr" Asad al Shidyaq, after years of confinement in the Maronite convent at Qannubin, for refusing to recant his beliefs), ${ }^{+6}$ of the attempted poisoning of Protestant converts ${ }^{47}$ and of tugs of war between the ecclesiastics and missionaries over the loyalties of the mountain Christians - not that the number won over to Protestantism ever amounted to more than a fraction of the whole - but the outcome of the battle could not be discerned while it was in progress and the patriarchs did everything they could to stem the advance of Protestantism. The political connections between the patriarchs and the Ottoman government, as well as the valis, pashas and amirs directly responsible for the administration of Ottoman Syria, were important weapons in their armory and will be considered later in this narrative.

\section{Missionaries in the Front Line}

The difficulties ahead of the missionaries were felt most acutely in the villages of the Ottoman provinces where they set up their stations. Istanbul and the main towns had achieved a level of sophistication, in addition to which there was the direct presence of the Ottoman government and foreign ambassadors or consuls from whom the missionaries could seek support and redress, but these layers of protection fell away the further they moved from the center of government. The incapacity (or refusal) of the missionaries to live among local people according to their own laws and customs was evident at an early stage. Conflict was inevitable. They regarded the "Muhammadan" government whose permission they needed to establish their schools and stations as corrupt and they frequently refused to accept the laws and conventions of the land. They were already looking ahead to the day when they could proselytize freely among Muslims as well as Christians and they 
took the laws and decrees issued by the government to mean what they wanted them to mean. They regarded the Hatti Humayun of 1856 as a charter opening the door to full religious freedom as they chose to interpret it: the Crimean War was seen as working to their advantage "as there was forced from the Sultan in 1856 the famous Hatti Humayun, a firman granting full freedom of conscience and religious profession to all his subjects. Religious liberty was now secured at least by decree ... ${ }^{n 8}$ Such an interpretation was vigorously denied by the Ottoman government. They could be extraordinarily disingenuous. Addressing the annual meeting of the ABCFM in New York in 1832, Eli Smith said that the missionaries did not wish to curse Muhammad but only "by sober and convincing argument to prove that he is a false Prophet." 49 The unspoken question left hanging in the air is "and who could possibly object to that?"

In the 1860s, the British ambassador Sir Henry Bulwer recorded in one of his dispatches how the missionaries had affirmed that while distributing their tracts they had "pointed out the errors of Mohametanism in a very civil and courteous manner and in fact I believe it was stated on one occasion that he was a capable man." ${ }^{\text {50 }}$ Seizing on the freedoms they chose to believe the Hatti Humayun had given them, the missionaries approached Muslims directly and even baptized the small number of them willing to convert, in the full knowledge that within the previous 20 years, Muslim apostates had been executed in the Ottoman Empire. This was not just a question of the laws and what they were supposed to mean but civil order because as Sultan Abdulhamit observed, "the public appearance of a converted Mussulman might lead to serious disorders and even a massacre or persecution for which he and his government would be held responsible." ${ }^{51}$ His ministers also vehemently rejected the "pretensions" of the missionaries regarding the Hatti Humayun, which in their interpretation ensured the right of each individual to profess his own religion without impediment but not the "right" to insult and cast doubts on the beliefs of others.

The missionary view of Ottoman sociery was basically adversarial. The path to Gospel truth was strewn with obstacles: the corruption and misrule of the "Muhammadan" Ottoman government; the fanaticism and narrowmindedness of the ecclesiastics of the Eastern churches; the ignorance of the "nominal" Christians needing to be retrieved and brought to a higher form of Christianity; and swirling all around them, Muslims led astray by a false prophet. In this sink of iniquity, injustice, fanaticism and superstition, only the missionaries knew the truth; in a sense it could be said that they were acting out the life of the early church in a region which had been "from the time of Paul one of the most promising fields for Christian work." ${ }^{52}$ The following passage about the early Christians written by Eusebius of Caesarea can be 
taken as a template for the lives of the Protestants who ventured forth into the "moral darkness" of Asia in the nineteenth century:

At that time [about the beginning of the second century] many Christians felt their souls inspired by the holy word with a passionate desire for perfection. Their first action in obedience to the instructions of the Saviour was to sell their goods and distribute them to the poor. Then leaving their homes, they set out to fulfil the work of an evangelist, making it their ambition to preach the word of the faith to those who as yet had heard nothing of it and to commit to them the books of the divine Gospels. They were content simply to lay the foundations among those foreign people: they then appointed other pastors and committed to them the responsibility of building up those whom they had merely brought to the faith. Then they passed on to other countries and nations with the grace and help of God. ${ }^{\text {i3 }}$

Equipped with their New England seminary zeal and certitude, the missionaries went forth into the field only to run up against the convictions of many others who thought that only they knew the truth. We should not be surprised that from one end of the Ottoman Empire to the other, the missionaries found themselves rebuffed, threatened and sometimes even physically cast out from the communities to which they had come (in all their apparent innocence) bearing the message of Gospel truth. Their position in Eastern Anatolia at a time of increasing ill-feeling between Muslims and Christians for reasons already given exposed some of them to criticism that they had allowed their sympathies for their Armenian proteges to draw them into actively encouraging the Armenian revolutionary movement. These charges were hotly denied but missionaries stationed in the remote Eastern provinces were in a weak position to defend themselves, and, in any case, there is no doubt that they were guilty of numerous "indiscretions" at the least, apart from the occasional more serious embarrassments such as the printing of revolutionary propaganda under their noses at Marsovan College. ${ }^{54}$ The Missionary Herald rushed to the defense of the two Armenian teachers arrested by the Ottoman government: "There was no evidence connecting them with the issuing of the placards and the charge seems to have been made with the purpose for furnishing the basis for an attack on the college." there was evidence and when it was shown to the principal of the college, he declared that "it was sufficient to cast the gravest doubts on Messrs Thoumayan and Kayayan and until the Turkish Tribunal had passed upon their innocence or guilt he should recommend to the trustees of the college that their names should be erased from the College Register." ${ }^{16}$ The college subsequently became the target of an arson attack. At Bitlis, a missionary accused of giving active support to the Hunchaks was escorted out of the town under armed 
Ottoman guard and fears were often expressed that all missionaries would be removed from the interior. Even in the confidential diplomatic correspondence of their own minister in Istanbul, the American missionaries were accused of meddling, engaging in secret correspondence with the British ambassador and providing material for the "atrocity articles" appearing in the British and American press. ${ }^{57}$ It certainly seemed to be the case that Ottoman ministers and Muslims alike believed that "the revolutionary societies in and out of Turkey had their origin in missionary instruction and that of all foreigners ours are the most dangerous to social order." 58

But even in less troubled times, objections to the missionary presence and activities were frequently and vehemently expressed. In 1825, missionaries Fisk and Bird were visited in their room in Beirut by the head of police accompanied by an armed guard and taken away for questioning by a "moolah or judge," who told them their firman had entitled them to travel but not to distribute books. He produced a copy of Genesis which the missionaries had handed out and threw it to the floor declaring "these books are neither Mussulman nor Jewish nor Christian" and when told that they were indeed the holy books of Christians, "his reply deserves to be remembered. The Latins say these are not Cbristian books." ${ }^{59}$ The missionaries were detained overnight and taken before "the governor," to whom they declared that they did not consider it unlawful for Muslims to read Christian books. Their room was temporarily sealed and eventually orders were received from the pasha in Damascus "stating that as we had a firman from the Sultan we must not be imprisoned or molested in any way." The outcome was satisfactory. "I believe all parties regretted that they had meddled with us," one of the missionaries wrote, "and I believe that a general impression was made that men under English protection are not to be trifled with." And, in their view, the whole episode came not from the opposition of the Turks but was rather "founded on the testimony of the Papists." ${ }^{60}$

Naturally, the Eastern churches would do all they could to block the advance of the Protestants and undoubtedly their repeated declarations inflamed feelings against the missionaries among the "nominal" Christians whom they sought to persuade. In Malta, the Wesleyan minister and his wife "were driven from their home by a furious Maltese mob... It was judged that not less than two hundred persons were assembled who threw stones with such violence as to break almost every pane of glass in the house and materially to injure the doors. ${ }^{.61}$ Visiting the Lebanese mountain village of Ihdin - close to the residence of the Maronite patriarchate - in 1828, missionary Bird ran into the direct opposition of the local people - "the family which entertained him was excommunicated by the Patriarch and the Maronites rose tumultuously, assaulted the house, beat and threatened the family and obliged 
Mr Bird to flee to Tripoli." ${ }^{\prime 2}$ Indeed the missionary's appearance appears to have caused a near riot. His host was clubbed and his daughter beaten when she went to bake bread at the communal oven. An old lady's wrist was broken. Missionary Bird and his family spent the night in trepidation. A stone was hurled down the chimney and for the greater part of the night "we heard the footsteps of men upon the terrace"; the next morning the family left the village but while still in the vicinity "a servant came ... and laying a paper on a stone at a little distance ran back as if he were afraid of the plague." The handwriting of the note Joseph recognized to be that of the priest and these were its contents: "Rise and quit this whole vicinity. If you are not off within five minutes time you will be saluted with a volley of stones." ${ }^{13}$

All of this was regarded by the missionaries as persecution. We know how the heads of the Eastern churches regarded the "Bible men" - as "beasts of prey" and followers of the devil, etc. - but what was the opinion of the Amir Bashir, the highest political authority in Lebanon? In a letter to the British consul, Bashir asserted that missionaries had traveled around the mountains without being molested "even to the value of a mustard seed." Missionary Bird's problems at Ihdin had all been of his own making. "It is indeed a fact that at the very moment of his arrival before he had time to rest he began to wrangle and contend about religious subjects; and you know sir, that to every person his own religion is dear. The people were moved and took offence at what he said and he being seized with fear fled before anyone had lifted a hand against him ... The blame and reproach in this case is all on Mr Bird for it is he that drew upon himself the disaster." ${ }^{64}$

This dramatic (and according to Bird's own account, dangerous) episode did not deter the missionaries. In 1849, they returned to Ihdin, hoping that in the twenty years since Bird had been driven out with his family, "even Papists had learned something during that long period and that we should be allowed to reside there in peace. ${ }^{65}$ Two houses were hired but shortly afterwards one of the owners came with a note written by a priest saying that Protestants were not wanted in Ihdin. He tried to give the rent money back but the missionaries refused to accept it. Returning to the village after a brief absence, missionaries Wilson and Foot found the houses occupied but Wilson managed to open the door of one and went in with their families. The word spread and a crowd gathered. "Several attempts were then made to fire the house; all of which failed. Their next attempt was to tear it down, a work which they began in good earnest, rolling stones off from the walls. The confusion now became very great and our ladies left the house while heavy stones were falling near the door through which they must needs pass." As Bird had done twenty years before, the missionaries left the village and camped in the open air before returning to Tripoli. A letter subsequently received from Ihdin informed them 
that the people "are determined in their opposition to us; and they say they will cut down their trees, burn up their houses and flee from their country before a Protestant shall be allowed to live among them." ${ }^{66}$ At other Maronite strongholds, the reaction was just as hostile. Missionary Benton and his family were physically ejected from Zahleh in 1859 after spending just two days there. First, boys entered their house and seized their books and then a crowd of townspeople returned. In the angry scenes which followed, the owner was among those injured but the main target was the missionaries. "Then the crowd poured into our room and with much force and violence seized us, carried us out of the house amid their clubs and stones and hurried us with our children and servants out of the town to Maallika where we sought and secured the aid and protection of the Turkish authorities. ${ }^{167}$

Two more episodes will suffice to round this picture of the awkward if not dangerous situations into which the missionaries projected themselves as a matter of religious duty. In 1836, missionary Smith hid a Druze convert to Christianity (and his two sons) from the authorities for a fortnight on the grounds that "according to the rights granted in this country to Europeans no-one would venture to take him without my leave or at least that of my consul.:68 In 1843 there was a tug of war in Beirut between the missionaries and the mother of a Christian girl. She had spent two years with the missionaries after her father had died and her mother had "lost her reputation" (as the missionaries asserted) and on eventually going back to the family house had been prevented from leaving. Fearing that she might be married that night or "delivered into the hands of the bishop," the missionaries went to the house with guards provided by the consul (presumably English or American) and succeeded in removing the girl. The next day, they took the precaution of lodging her in the house of the Prussian consul-general. "You might say that all of this looks very much like taking the law into or own hands and so it does" admitted missionary Smith, "but then it was the plain law of the land that that we executed; and we did it ourselves because we had no confidence that this weak and corrupt government would do it for us and the emergency required haste. ${ }^{169}$ The girl's fate very quickly became a diplomatic issue. In the morning, the Russian dragoman "presented a complaint from the mother to the pasha charging the janissaries with having beaten and wounded her other daughter and me with having forced Rahil away contrary to her will and for sinister purposes." The pasha then asked the American consul to have the girl brought before him but his reply was that he could not because she was now under the protection of the Prussian consulate. The mother then appeared before the pasha and "confessed" that the girl had left of her own volition. The girl eventually was brought before him and said the same thing. The Greek bishop became involved but the girl said she was not answerable 
to him and that finally she was free to what she wants, an outcome which the missionaries again interpreted (grandiosely) as upholding the right of Christians to become Protestants or members of any other sect.

\section{The Muslims - Challenge and Temptation}

Proselytizing among Muslims was even more dangerous than it was among Christians. The death penalty for apostasy was applied until 1844 and open approaches to Muslims, however disingenuously presented by the missionaries, could and did result in public disturbances. The Shari' $a b$ was the law of the land and the entire structure of Ottoman authority was underpinned by the legitimacy of the sultan as a Muslim ruler. The Ottoman government could not possibly tolerate any questioning of the truth of Islam. It could only be seen as subversive and as having dangerous practical consequences and it was in the face of these realities that the missionaries were advised to tread cautiously when dealing with Muslims. This did not stop them from looking forward to the day when they could proselytize openly and grabbing eagerly at the reform decrees issued by the sultan as proof that their "right" to seek Muslim converts had now been granted - an interpretation which (as has been already pointed out) the Ottoman government did not share. There was another consideration to be added to these difficulties and that was the example of Eastern Christianity to the Muslims. Its condition was scandalous: false beliefs, a corrupt, fanatical, self-serving and immoral priesthood and a people kept in superstition and ignorance. Looking at all of this why would Muslims even want to become Christian? Thus it was that the elevation of Eastern Christianity to a higher stage was regarded by the missionaries as a prerequisite for approaching Muslims. "The Turks as a body have never yet seen anything like a fair exhibition of Christian character," missionary Dwight wrote in 1830. "Who can wonder that they should look down with contempt on the mummery and nonsense in the shape of religious rites which they every where see in the professedly Christian churches of this country?" ${ }^{70}$ In its instructions to Cyrus Hamlin on the occasion of his departure for the Ottoman Empire, the Prudential Committee of the ABCFM wrote: "The object of our missions to the oriental churches is first, to revive the knowledge and spirit of the gospel among them; and secondly by this means to operate among the Mahommedans." ${ }^{71}$ According to instructions given to the missionaries as reproduced in the Missionary Herald: "The Mohammedan nations cannot be converted to the Christian faith while the oriental churches existing everywhere among them as the representatives and exemplifications of Christianity continue in their present state." ${ }^{172}$

These were the difficulties but the harvest was so promising that missionaries frequently could not resist the temptation of the direct approach. 
British missionaries once planned to declare the Prophet Muhammad an impostor from the precincts of Aya Sofia and when they and American missionaries began handing out religious tracts from rented rooms in Istanbul in the 1860 s, the Ottoman government responded with alacrity, closing down both their rooms and their assembly halls on the grounds that their activities were putting public order at risk. The missionaries and their supporters reacted with outrage but one only has to consider the kind of material they were handing out to understand the impact it would have had on Muslims: Proofs of the Falsebood of the Mabometan Religion was the title of one tract and the Rev. Carl Pfander's The Balance of Truth (Mizan al Haqq) was another. Pfander had traveled widely through the Muslim world, had lived in Baghdad, Persia and India and had spent 12 years among Muslims in the Caucasus without apparently changing his views. Of Pfander, Avril A. Powell has written: "Like most European observers of his generation his mind was entirely closed to the idea that Muslim civilization had thrown up any achievements either in the past or the present which might bear favorable comparison with the cultural and scientific progress he associated with Western Christendom. ${ }^{73}$ It is not surprising to read that Sir William Muir wrote The Mohamedan Controversy to attract wider support for Pfander: it was, after all, Muir who wrote that "the sword of Muhammad and the Kor'an are the most stubborn enemies of civilization, liberty and truth which the world has known." ${ }^{.74}$ On that point, he and Pfander appeared to be in full agreement.

Other missionaries met with a similar response when they approached Muslims directly. In 1827 Joseph Wolff, an agent for the Society for the Promotion of Christianity Among the Jews, took it upon himself to issue a manifesto to the "Mahometan grandees" of Alexandria urging them to repent and "return" to Christianity. That was risky enough but when he sent one of his "calls" to the governor, his messenger was flogged and he himself subsequently expelled. ${ }^{75}$ The accumulation of these experiences did not deter some missionaries and virtually all of them looked forward to the day when Ottoman Muslim power could be overthrown. Some regarded every misfortune suffered by the Ottoman Empire as a step forward. "Were not all of you disappointed that the Russian army did not march at once upon the capital and annihilate by force the dominion of the successors of Muhammad?" missionary Eli Smith asked his audience at the annual meeting of the ABCFM in $1832 .{ }^{76}$ But perhaps the "grand prize" denied the Russians had been reserved for missionary enterprise to win "by converting Moslems to the faith of Jesus." Even martyrdom was seen as a means towards this end. In a letter written in 1824 on the subject of the conversion of Muslims, we find missionary Fisk in a contemplative mood: 
My mind dwells with deep interest on the question "how is the Gospel to be preached to the Mussulmans"? According to the established law, and a law which to the extent of my information is rigidly executed, it is immediate death for any Mussulman, of whatever rank in whatever circumstances to renounce his religion. Undoubtedly God can so pour out his spirit upon men that they shall embrace the Gospel in multitudes even with the certainty of immediate death. But has he ever done this? Has the Gospel ever prevailed where this was the case? Under the pagan emperors fiery persecutions were endured and the Gospel still prevailed. But in these persecutions it usually was only some of the principal persons or at least a part of the Christians that were put to death. Perhaps if a few conversions should take place and be followed by immediate martyrdom the blood of the martyrs would again prove the seed of the church and the persecutors cease from their opposition, Possibly the bloody and fiery scenes of the first centuries are to be acted over again. Possibly some great political revolution is to open the door for the free preaching of the Gospel to the followers of the false prophet. $^{77}$

In 1837, missionary Bird also referred to the Shariab against apostasy yet "in the assailable parts however of the Mohammedan world where their discipline is lax or where the government is not their own it is time to begin to press them with the difficulties of their system and to exhibit these difficulties in contrast with the perfect system of Christ." ${ }^{78}$ The conflict between the Ottoman government and Muhammad 'Ali should be regarded as a providential sign for the possibility of labor among the Muslims. "We see the kingdom divided among itself ... Since the late civil war Moslems have learnt to feel that their kingdom is weak and on the verge of ruin" and a spate of rumors about the state of government "whether believed or not betray a strong feeling of distrust in their civil and spiritual head and betoken the entire breaking up of the Mohammedan system of delusion." ${ }^{79}$

But even Bird recommended prudence and generally it seems to have been regarded as the better part of valor, which is probably just as well given the hostility to Islam that seeps out of missionary correspondence. There is little more that needs to be said about it. References to the "Muhammadan delusion" or "imposture" or to their "false prophet" pepper their pages. They could certainly look out for receptive minds and if Muslims were willing to take the risk they could even baptize them (although years of toil never brought them more than a handful of conversions) but basically they had to wait until time and providence created more favorable circumstances. By and large, Muslims were not receptive to their views. They were likely to be offended and even outraged by them and the Ottoman government would not tolerate open proselytism whatever "rights" the missionaries thought they had 
under Ottoman law. All of this put the missionaries in the position of watchers at a banquet gazing hungrily at food they were prevented from eating.

\section{Altruism and Imperialism}

The question arises as to whose ends the missionaries were serving (apart - presumptively - from God's). In the various lands to which they went what else were they representing besides Gospel truth? In the eyes of the native population, it was European power, appearing in a variety of disguises but always with the same purpose of domination and control of minds as well as territory and resources. As Stephen Neill has written, ". . for say what we will, Christian missionary work is frequently understood by the people of Africa and the East not as the sharing of an inestimable treasure but as an unwanted imposition from without, inseparably associated with the progress of the colonial powers. ${ }^{n 0}$ The missionaries went abroad fully equipped with notions of racial and civilizational superiority common to European man. The historical differences between the English and the Americans all fell away in the local setting before the common unifying truths. Whether in the Ottoman Empire or in India or China or in the Sandwich Islands, the missionaries were not only the bearers of Gospel truth but came as representatives of the AngloSaxon 'race' and the representatives more generally of a superior civilization in all material and spiritual aspects. These were self-evident truths and the failure of others to see them (even worse to oppose them) led to the frustration, disappointment and irritation that is constantly to be found in missionary records and correspondence. Their unwavering belief in their mission could only lead to the condemnation of societies, laws and customs that did not meet their standards. There could be no shades of grey. The missionaries could certainly recognize individual good, but systems, cultures and histories that lacked the basic ingredients of "Western civilization" could only be regarded as deficient if not downright evil (here the Protestants did not show as much flexibility when encountering foreign cultures as the detested Papists sometimes did). Thus, the caste system in India had to be swept away and so did "Muhammadan government" wherever it was encountered. There was no self-analysis or questioning except in the most disingenuous and superficial sense: the object of Carl Pfander's tract was not genuine religious debate but propaganda. Against Gospel truth there could be no other truths and insofar as "civilization and progress" was attainable, it could only be according to the Western/European/Protestant model. "Only Western man was wise and good and members of other races in so far as they became Westernized might share in this wisdom and goodness. But Western man was the leader and would remain so for a very long time, perhaps for ever." ${ }^{n 1}$ 
This does not mean that the missionaries were the conscious agents of imperialism. The affinities of the American missionaries with the English were more along cultural, religious and civilizational lines than political. Not that the missionaries were unaware of political realities. Even in the late $19^{\text {th }}$ century, the relationship between the US and British governments was fraught with difficulties (such as the application of the Monroe Doctrine and their competing interests in Latin America). But the pressure the British government could bring to bear on the Ottoman government was far greater than anything their own government could muster and the American missionaries knew it and frequently sought to use it in their own interests. Well before the development of the Orientalist critique the missionaries also knew that knowledge is power: they were the most indefatigable collectors of information towards the general end of strengthening their mission work. But the side benefits for any student of Ottoman society in the $19^{\text {th }}$ century are works such as W. M. Thomson's The Land and the Book: the people and the way they live, the crops they grow and even the flora and fauna to be found across the land are richly detailed. The relationships between missionaries and governments were complex. The ABCFM missionaries benefited from the diplomatic and consular protection of their own government and of the British, whose help they acknowledged as being critical when they were establishing themselves in Ottoman Syria. As well as being aware of what European power could achieve in the face of a recalcitrant Ottoman government, they shared the prejudice common to European diplomats that the Ottomans would only introduce reforms under threat or pressure. Each setback suffered by the Ottoman government was interpreted as a sign of the final downfall of a system which they detested. These general attitudes come through clearly in their correspondence. Leading missionary figures maintained contact with politicians (pre-eminently William Gladstone) and provided newspapers in England and the United States with information during the violent disorders that swept Istanbul and the Eastern provinces of the empire from 1894 to 1896. The outraged reaction included demands that the U.S. government send gunboats to Turkish waters with the authority to bombard Ottoman ports if necessary (the same pressure for military intervention was being made in Britain by politicians and religious groups associated with the "forward Armenia" movement).

Missionary involvement was instrumental in highlighting the need for foreign governments to protect Ottoman Christians and therefore strengthened the case being argued from time to time for European intervention on humanitarian grounds. However, to take just the example of the British government and its involvement in the Armenian question, while there was no doubt genuine solicitude, the more important motive from Britain's point of 
view was the need to prevent the Armenians from being used by Russia as leverage to strengthen its own position vis-á-vis the Ottoman Empire. That self interest was more important than humanitarianism would seem to be indicated by the fact that when Lord Salisbury decided in the 1890s that Britain would be better off concentrating its attention on Africa, ${ }^{82}$ the Armenian policy followed since the Congress of Berlin and the Armenians themselves were effectively abandoned.

But however much diplomats and governments might sympathize with the humanitarian and religious activities of the missionaries and might even profit from them, it is clear that the missionary presence in the Ottoman Empire was frequently the cause of frustration and irritation. They often made demands that could not be met or they would get themselves into awkward situations which the diplomats would have to sort out and which only caused strain between themselves and the Ottoman government, yet they had to be handled carefully because of the strong support they enjoyed both in the United States and Britain. The diplomat who went too far in upbraiding the missionaries would soon feel the lash across his back. For appearing to sympathize with the Maronite patriarch and the Ottoman authorities over the question of proselytism in 1841 the U.S. minister at Istanbul, David Porter was very quickly pulled into line by his own government and told to give American citizens "that aid and protection to which they feel themselves entitled. ${ }^{n 33}$ In 1864, after criticizing missionaries for imprudent behavior, the British Ambassador, Sir Henry Bulwer, was roundly abused by two of the most senior missionary figures, George Washburn and Cyrus Hamlin. ${ }^{84}$ Thirty years later, missionary "meddling" and "indiscretions" and finally the abuse of him which appeared in the "missionary press" appear to have totally infuriated the American Minister Plenipotentiary to the Sublime Porte, Alexander Terrell, and indeed to have strongly influenced his decision to resign. In his letter of resignation to President Cleveland, he conceded that some of the missionaries were good people but some were "bad and dangerous."

This deep official ambivalence about the missionaries can be found in other sources. W. M. Ramsay, for example, in Impressions of Turkey During Twelve Years Wanderings (1897), refers to the "missionary stumbling bloc" standing between the United States government and the Sultan. ${ }^{86}$ Their good work and Christian dedication could be admired. They were a strong part of the Western presence in Eastern lands and were furthering the goals of civilization and progress, but they could not be controlled and that was what made them dangerous. They were capable of guile and dissembling but in pursuit of Christian truth (as they saw it) they could be as obdurate and troublesome with their own governments as they were with the Ottomans. They could not easily be persuaded to retreat from what they considered to 
be their rights whatever the dangers and embarrassment these threatened to cause diplomats and their governments. Sir Edmund Hornby, a consular court judge and a defender of the missionaries in other circumstances, wrote in apparent exasperation that they were "next to habitual criminals the most troublesome people in the world to deal with." ${ }^{n 7}$

The missionaries were part of a slowly encroaching Western presence and in numerous ways, directly and indirectly and objectively if not subjectively, strengthened the capacity of the West to dominate the East. They provided the outside world with the knowledge that could be used as the leverage for intervention in Ottoman affairs. They brought into Ottoman society ideas that were regarded as dangerous by the authorities: according to Alexander Terrell, "the Turks believe that Robert College as the educator and encourager of free thought caused them the loss of Bulgaria" and the college remained an object of suspicion in his time. ${ }^{8}$ According to Richard Davey, in The Sultan and His Subjects (1897), "The only fault to be found with the American missions is that their teaching is a little too thoroughly 'go-ahead' to suit the conditions in which the pupils are eventually destined to live. Whether justly or unjustly, I cannot say, official Turkey views them with suspicion as being centres of revolutionary propaganda. One or two of the missionaries have frankly admitted to me that the education which the Armenians in Asia Minor were receiving - not from themselves only but from Roman Catholic Dominican, Lazarist and Jesuit missionaries - might tend to render the rising generation dissatisfied with its lot, adding, however, that the Armenians are so exceedingly intelligent that it seems a pity not to afford them every possible opportunity for improving themselves and of rising in the scale of civilization. ${ }^{1,89}$

This, one thinks, was the real danger presented by the missionaries. Their religious ideas were annoying, niggling and caused problems to the patriarchs of the Eastern churches, the Ottoman government and their own diplomats alike. But the secular ideas they brought with them and imparted through their schools alongside Gospel truth struck at the bases of Ottoman authority. They left behind very few converts to Protestantism from the Eastern rites. Islam was even more impervious: only a tiny number of Muslims ever converted to Christianity. We are told that the Reformed Church mission at Muscat converted only five Muslims in 50 years. ${ }^{90}$ This is the irony - that their legacy was not religious truth but rather the spread of secular ideas disseminated through their schools and colleges.

Attached to the central narrative of the American missionary presence in Ottoman lands is a number of other stories. The missionary experience is also the story of the country from which they came. Their confidence and idealism and the values the missionaries brought with them and reflexively assumed 
were right for everyone else tell us something of the state of American society at the time they took sail for the Ottoman Empire. Another story speaks of the juxtaposition of two societies - one entering a period of rapidly gathering cohesion and dynamic growth and the other falling even deeper into a state of decline which no reform proved capable of arresting. Yet another element is what stands to be learned when morality is injected into international relations and the affairs of governments. The moral and religious concerns of the missionaries might attract the sympathy and even the support of diplomats and governments, but only to a point defined by national self-interest. In the case of official British interest in the Armenians, humanitarian concern rose or diminished but never moved above this line. A politician such as W. E. Gladstone, a self-consciously moral and religious figure, was only possibly an exception. By the time the Armenian question had reached the point in the 1890 s where intervention was being demanded in the name of morality, he was out of office and could only wring his hands at the refusal of the Conservatives to do more. The insistence of the missionaries on morality above politics inverted the code of governments and diplomats, among whom they aroused not just ambivalence but frustration and even anger: the true imperialists did not quite regard them as belonging to the same club. Certainly many of the missionaries were sympathetic to the imperialist idea: in the context of the nineteenth century, that is only to be expected, but there were as many attitudes as there were missionaries and in any case their overriding concern was their commitment to the spreading of Gospel truth. The Americans of the ABCFM saw themselves as doing God's work on earth and not as serving the temporal interests of any particular power, whatever their individual sympathies and affinities. This made them unreliable allies. It is for this reason that their place in imperial and colonial history is so idiosyncratic even though they served "Western interests" in the general sense by their presence and the values they disseminated.

\section{Endnotes}

1. Jeremy Salt, Imperialism, Evangelism and the Ottoman Armenians 1878-1896 (London: Frank Cass, 1993), 23, quoting Cyrus Hamlin.

2. Ibid., 20.

3. Moshe Ma'oz, Ottoman Reform in Syria and Palestine 1840-1861 (Oxford: Oxford University Press, 1968), 160.

4. William E. Strong, The Story of the American Board. The Centenary of American Foreign Missions (Boston: Pilgrim Press, 1910), 9.

5. Ibid., 17.

6. Ibid., 17-18.

7. Ibid., 30 . 
8. Ibicl, 80 .

9. Ibid., 81 .

10. Edwin M. Martin, The Hubbards of Sivas (Santa Barbara: Fithian Press; 1991), quoting the U.S. consul at Sivas, H. M. Jewett.

11. Kamai Salibi and Yusuf K. Khoury, eds., The Missionary Herald: Reports from Ottoman Syria 1819-1870 (Amman, Jordan: Royal Institute for Inter-Faith Studies, 1995), vol. 3, 1836-1846, Instructions of the Prudential Committee to Rev. Cyrus Hamlin on the occasion of his recent departure for Turkey, 164.

12. Strong, op. cit., 90.

13. Ibid., 92.

14. Ibid.

15. Autobiography of William G. Schauffler. For Forty Nine Years a Missionary in the Orient. Edited by his sons (New York: Anson D. F. Randolph and Company, 1887), 135.

Among Schauffler's contemporaries at Andover were two of the leading missionary figures of the nineteenth century, Dr. H. G. O. Dwight (his roommate) and Dr. Elias Riggs.

16. Richard Davey, The Sultan and bis Subjects (London: Chapman and Hall, 1897), vol. two, 223.

17. Strong, op. cit., 103.

18. The Missionary Herald, volume three, 162-63.

19. Ibid., volume two 1828-1835. Extracts from a communication of Mr Goodell on "The Cause of Opposition to Protestant Doctrines in Syria," 164.

20. Ibid., 165.

21. Strong, op. cit., 167, referring to an Armenian bishop.

22. The Missionary Herald, reports etc. vol. 2, 163.

23. Ibid., vol. I, a letter from missionary Fisk, 277.

24. Ibid., vol. 2, "Extract from the journal of Mr Bird," 88.

25. Ibid., vol. 2, "journal of Mr W. M. Thomson at Beyroot and on Mt. Lebanon" December 9, 1835, 93.

26. Ibid., vol. 4, 1847-1860, 60.

27. Salt, op. cit., 33 .

28. Strong, op. cit., 92.

29. Schauffler, op. cit., 93.

30. Ibid., 131.

31. Strong, op. cit., 105.

32. Schauffler, op. cit., 180.

33. Ibid., 190-91.

34. Strong, op. cit., 215.

35. Martin, op. cit., 96.

36. Ibid., 99-100.

37. Ibid., 96.

38. The Missionary Herald, Reports etc. vol. 1 from a letter of missionary Goodell, 235.

39. Ibid., vol. 1, 480

40. Ibid., vol. $2,11$.

41. Ibid., 75 .

42. Ibid., vol. 1, 144 .

43. Ibid., vol. 3,82 .

44. Ibid., vol. 4 letter from $\mathrm{Mr}$ Whiting, dated June 22, 1848 on "persecution at Hasbeiya," 60.

45. Ibid., vol. 4,62 .

46. Ibid., vol. 2, see 321-323 for a history of the sulferings of Asad al Shidyaq. 
47. Ibid., vol. 4, 350 .

48. Strong, op. cit., 196: emphasis in the original.

49. The Missionary Herald, reports etc. vol. 2, 344 .

50. Salt, op. cit., 36 .

51. Ibid., 35 .

52. Stephen Neill, A History of Cbristian Missions, revised by Owen Chadwick (Penguin 1964: 1986 and 1990), 29.

53. Ibid., 35 .

54. Salt, op. cit., 65 .

55. Martin, op. cit., 217, quoting The Missionary Herald.

56. Salt, op. cit., 66.

57. Ibid., 115.

58. Ibid., 117, quoting the U.S. Minister Plenipotentiary at Istanbul, Alexander Terrell.

59. The Missionary Herald, reports etc. vol. 1, 286 et. seq. Emphasis in the original.

60. Ibid., 293.

61. Ibid., 320 .

62. Ibid., vol. 2,7 .

63. Ibid., $87-88$.

64. Ibid., 109.

65. Ibid., vol. 4, 96.

66. Ibid., 97.

67. Ibid., letter from Mr. Benton, May 24 1859, "Violent Expulsion from Zahleh," 343.

68. Ibid., vol. 3, letter from Mr. Smith, Beirut, March 17, 1836, 65-69.

69. Ibid., letter from Mr. Smith February 27, 1843 on "Toleration of Protestants," 382.

70. Ibid., vol. 2, extracts from a letter of Mr Dwight's April 9, 1830, 253.

71. Ibid., vol. 3, 160 .

72. Martin, op. cit., 95, quoting the Missionary Herald of September 1839.

73. Avril A. Powell, Muslims and Missionaries in Pre-Mutiny India (Curzon Press, 1993), 152.

74. Sir William Muir, Life of Mabomet from Original Soutres, new edition (London: 1877), 535. See also Clinton Bennett, Victorian Images of Islam (London: Grey Seal, 1992), 109 and 111 for reference to Muir's support of Pfander — "the most distinguished opponent of Islam that has yet appeared."

75. H. P. Palmer, Joseph Wolff (London: Heath Cranton Limited 1935), 153.

76. The Missionary Herald, reports. Etc. vol. 2, 348.

77. Ibid., vol. 1, 251, journal of Mr Fisk on the subject of the "conversion of Mussulmans."

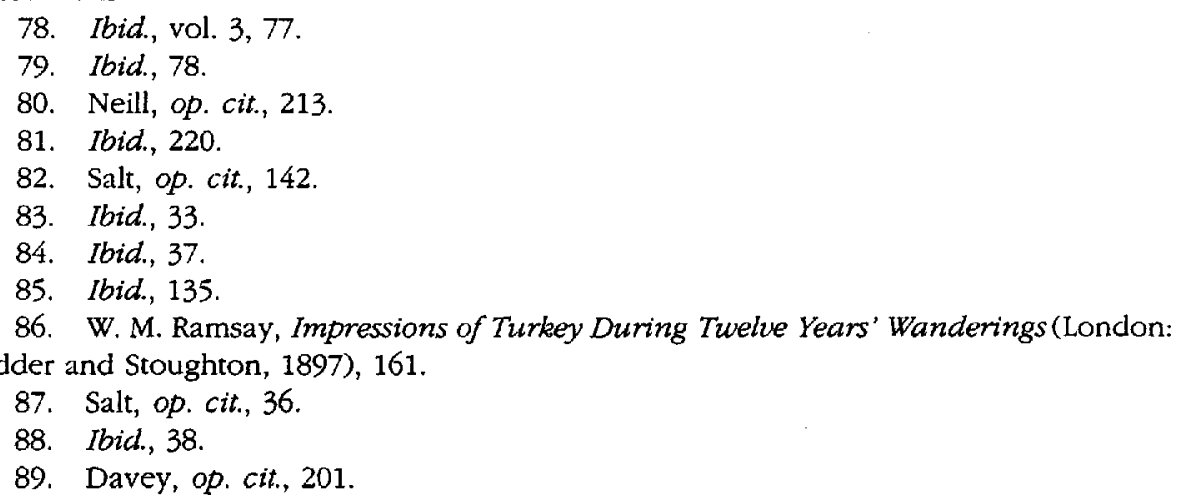


90. Neill, op. cit., 311, referring to the acrivities of Samuel M. Zwemer, one of the leading figures in Christian mission work in the Persian Gulf. His attitudes in the chapter subtitles of Zwemer's Islam. A Cballenge to Fatth (first published 1907, London: republished by Darf Publishers, 1985) give some flavor of his views - "the problem and the peril," "the danger in West Africa," "the parable of the locusts," "Moslem morals in India," "their low ideal of character" and "the social bankruptcy of Islam." 